\title{
POPs in Sparus auratus Species from the Eastern and Western Egyptian Mediterranean Coast: A Health Hazard Study
}

\author{
Tarek O. Said1,2, Mohamed A. Mansour'1, Fahmy M. El-Sharkawi'3, Manal A. Mohamed ${ }^{3}$, \\ Mohamed A. Shreadah ${ }^{1}$ \\ ${ }^{1}$ National Institute of Oceanography and Fisheries, Alexandria, Egypt \\ ${ }^{2}$ Chemistry Department, College of Science, King Khalid University, Abha, KSA \\ ${ }^{3}$ Environmental Health Department, High Institute of Public Health, Alexandria University, Alexandria, Egypt \\ Email: niof@hotmail.com
}

How to cite this paper: Said, T.O., Mansour, M.A., El-Sharkawi, F.M., Mohamed, M.A. and Shreadah, M.A. (2017) POPs in Sparus auratus Species from the Eastern and Western Egyptian Mediterranean Coast: A Health Hazard Study. Open Journal of Marine Science, 7, 317-326.

https://doi.org/10.4236/ojms.2017.72023

Received: October 17, 2016

Accepted: April 27, 2017

Published: April 30, 2017

Copyright $\odot 2017$ by authors and Scientific Research Publishing Inc. This work is licensed under the Creative Commons Attribution International License (CC BY 4.0).

http://creativecommons.org/licenses/by/4.0/

\begin{abstract}
The residual concentrations of HCHs, TC, DDTs, THCs and PCBs were measured in Sparus auratus collected from the eastern and western sectors of the Egyptian Mediterranean Sea, as the most common fish species in the area. Gas chromatograph equipped with ${ }^{63} \mathrm{Ni}$-electron capture detector and 35\% phenyl polysilphenylenesiloxane capillary column was used for the analysis and quantification after well-established extraction techniques. The concentrations (wet weight) of PCBs, DDTs, TCs, HCHs were: $\left(1.87-616.66 \mathrm{ng} \cdot \mathrm{g}^{-1}\right)$, $\left(0.42-98.28 \mathrm{ng} \cdot \mathrm{g}^{-1}\right),\left(0.06-2.94 \mathrm{ng} \cdot \mathrm{g}^{-1}\right),\left(0.35-11.77 \mathrm{ng} \cdot \mathrm{g}^{-1}\right)$, respectively in Sparus auratus collected from the eastern sector. However, these concentrations as wet weight in Sparus auratus from the western sector were: (5.75 $\left.605.53 \mathrm{ng} \cdot \mathrm{g}^{-1}\right),\left(1.53-226.47 \mathrm{ng} \cdot \mathrm{g}^{-1}\right),\left(0.09-8.12 \mathrm{ng} \cdot \mathrm{g}^{-1}\right),\left(0.26-5.80 \mathrm{ng} \cdot \mathrm{g}^{-1}\right)$, respectively. In general, concentrations of pesticides and PCBs in Sparus auratus either from the western or eastern Egyptian Mediterranean coast were far below the international permissible levels.
\end{abstract}

\section{Keywords}

Pesticides, PCBs, THC, Sparus auratus, Mediterranean, Egypt

\section{Introduction}

Contamination of the Egyptian Mediterranean Coast has become a subject of a great deal of research in recent years. The continuing and increasing release of a great number of industrial, agricultural, commercial and domestic waste effluents and emissions as well as hazardous substances have affected the characteris- 
tics of water [1]-[7], sediments [8]-[15], and fish which is most commonly chosen because of the implications it carries for human consumption and health risk [16] [17] [18] [19] [20]. Major concern has been directed to persistent organic pollutants (POPs) as they are highly resistant to degradation by biological photolytic and/or chemical means [21] [22] [23]. These compounds were found widespread in the environmental media, humans and wildlife, and globally distributed including remote areas where they have never been used [24]. POPs are used to refer to organic compounds whose presence in the environment in very small amounts can cause significant harm to ecological systems and/or humans [25]. This study was aimed to compare the concentration levels of POPs in tissues of Sparus auratus as the most economical marine fish species in the eastern and western sectors of the Egyptian Mediterranean Sea.

\section{Materials and Methods}

Biota samples, Sparus auratus species, were collected fresh from 12 stations by fishermen working in the Eastern and western sectors of the Egyptian Mediterranean Sea during 2010 (Figure 1), no more than $2 \mathrm{~h}$ after catching and then kept frozen in the laboratory. Biological specimens were dissected and their tissues were kept frozen until extraction. Fish tissue (10 g of wet wt. of flesh) as placed in a blender, and $30 \mathrm{~g}$ of anhydrous sodium sulphate was added. Samples were blended at high speed until the mixture was well homogenized ( $2-3 \mathrm{~min})$. The mixture was then transferred to a pre-cleaned extraction thimble and the dehydrated tissue was extracted with $200 \mathrm{ml}$ (1:1) of n-hexane-dichloromethane for $8 \mathrm{~h}$ in a Soxhlet apparatus cycling $5-6$ times $^{-1}$. Anhydrous sodium sulphate $(30 \mathrm{~g})$ was extracted in the same fashion as the sample and used as the blank. The extracted solvents were concentrated with a rotary evaporator and concentrated with a pure nitrogen gas stream down to a volume of $2 \mathrm{ml}$ [26] [27]. Clean-up and fractionation were performed by passing the extract through a silica/alumina column. Elution was performed using $70 \mathrm{ml}$ of hexane for PCBs congeners (F1), followed by elution with a $50 \mathrm{ml}$ mixture containing $70 \%$ hexane and $30 \%$ dichloromethane for pesticide fraction (F2). Finally, eluted samples

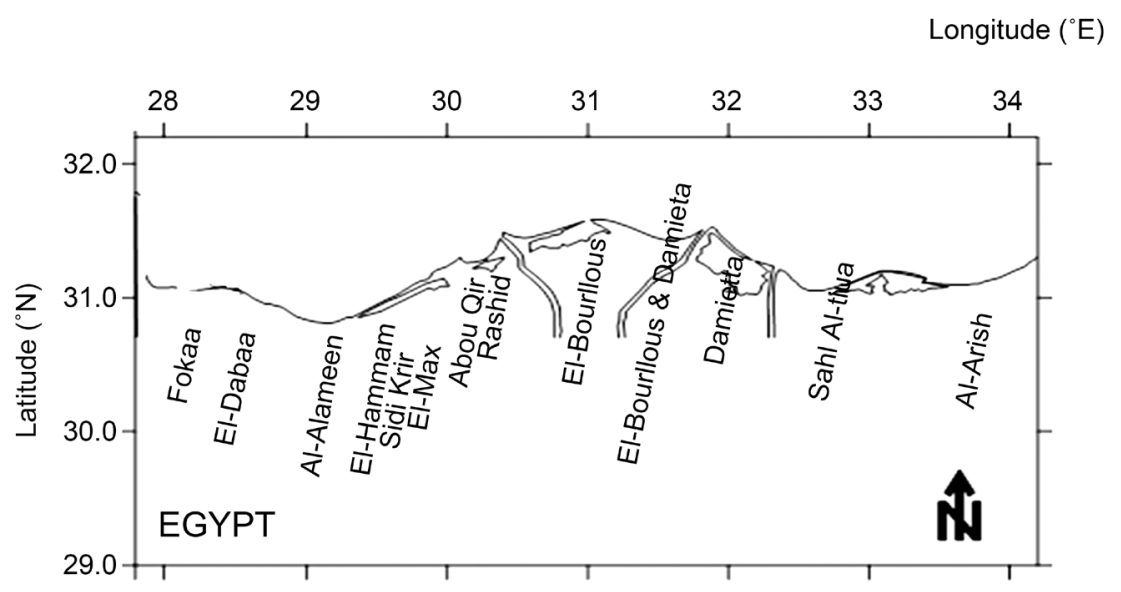

Figure 1. Sampling stations of the study area. 
were concentrated under a gentle stream of purified nitrogen to about $0.2 \mathrm{ml}$, prior to injection into GC/ECD for analysis. All samples were analyzed by a Hewlett Packard 5890 series II GC gas chromatograph equipped with a ${ }^{63} \mathrm{Ni}$ electron capture detector. The instrument was operated in split less mode $(3 \mu \mathrm{L}$ split less injection) with the injection port maintained at $290^{\circ} \mathrm{C}$ and the detector maintained at $300^{\circ} \mathrm{C}$. A fused- silica capillary column; Thermo TR-35 MS (30 m, $0.25 \mathrm{~mm}, 0.25 \mu \mathrm{m}$ ) with $35 \%$ phenyl polysilphenylenesiloxane was used for the quantification. The temperature was programmed from $90^{\circ} \mathrm{C}-140^{\circ} \mathrm{C}$ with rate of $5^{\circ} \mathrm{C} \mathrm{min}{ }^{-1}$, then held at $140^{\circ} \mathrm{C}$ for $1 \mathrm{~min}$, and from $140^{\circ} \mathrm{C}-250^{\circ} \mathrm{C}$ with rate of $3^{\circ} \mathrm{C} \mathrm{min}^{-1}$ and was held at $250^{\circ} \mathrm{C}$ for $1 \mathrm{~min}$, and from $250^{\circ} \mathrm{C}-300^{\circ} \mathrm{C}$ with rate of $20^{\circ} \mathrm{C} \mathrm{m^{-1 }}$ and was held at $300^{\circ} \mathrm{C}$ for $1 \mathrm{~min}$. The injector and detector temperatures were set at $280^{\circ} \mathrm{C}$ and $310^{\circ} \mathrm{C}$, respectively. Three $\mu \mathrm{L}$ volume of each sample was injected in the split less mode and the purge time was $1 \mathrm{~min}$. To control the analytical reliability and assure recovery efficiency and accuracy of the results, four analyses were conducted on organochlorine compounds reference material SRM-2974 a freeze-dried muscle tissue (Mytilus edulis) provided by EIMP-IAEA. The laboratory results showed that recovery efficiency ranged from $90 \%$ to $105 \%$ with coefficients of variation of $8 \%-15 \%$ for all organochlorine compounds. The limit of detection in the present study was estimated to be $0.014 \mathrm{ng} \cdot \mathrm{g}^{-1}$ for PCB and $0.014 \mathrm{ng} \cdot \mathrm{g}^{-1}$ for pesticides based on the minimum quantity of sample required for a discernible peak appeared on the chromatogram.

\section{Results and Discussion}

Muscles of fish showed the presence of a wide variety of organochlorines including $\alpha, \beta$ and $\gamma-\mathrm{HCH}$, dieldrin, aldrin, endrin, DDT and their metabolites as well as PCBs (Table 1 and Table 2). The mean composition of OCPs in Sparus auratus was $17.96 \%, 6.46 \%, 75.54 \%$ for HCHs, TCs and DDTs, respectively. DDTs composition was much higher than HCHs and TCs, which might be attributed to the more bio-accumulative ability of DDTs (Table 1). Low concentrations of $\mathrm{HCHs}$, which were recorded in fish tissues of the present study, reflect their lower potential for bioaccumulation than other pesticides. Furthermore, higher vapour pressures of $\mathrm{HCHs}$ facilitate relatively rapid atmospheric dissipation in the tropics, leaving fewer residues in soil and water [28]. The most striking difference in $\mathrm{HCHs}$ composition of the investigated Sparus auratus (approximately $18.30 \%$ of $\alpha-\mathrm{HCH}, 70.48 \%$ of $\beta-\mathrm{HCH}$ and $11.23 \%$ of $\gamma-\mathrm{HCH}$ ) is the high level of $\beta$ - $\mathrm{HCH}$ was the predominant isomer of $\mathrm{HCHs}$ which can exist in the environment for several years because they are stable, resistant to microbial degradation, and have a long half-life with a low solubility and vapour pressure [29]. Although, aldrin is readily converted to dieldrin in many environmental compartments, the mean composition of Aldrin, Dieldrin and Endrin in Sparus auratus of the present study was $13.87 \%, 19.08 \%$ and $67.05 \%$, respectively. This indicates that there is a weathered source of Aldrin with sufficient oxygen available for the oxidation process to its epoxide form; Dieldrin. Endrin is highly 


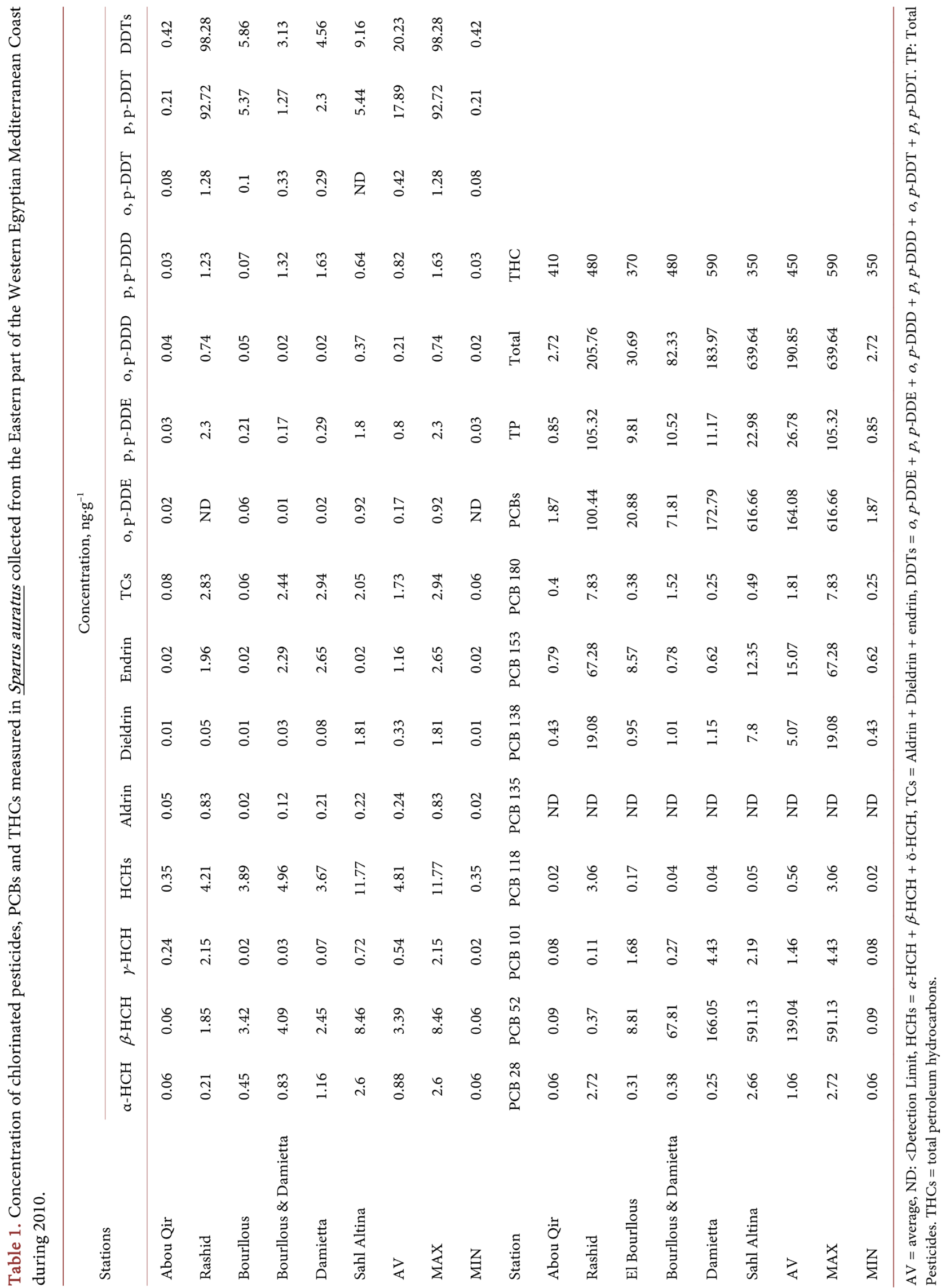




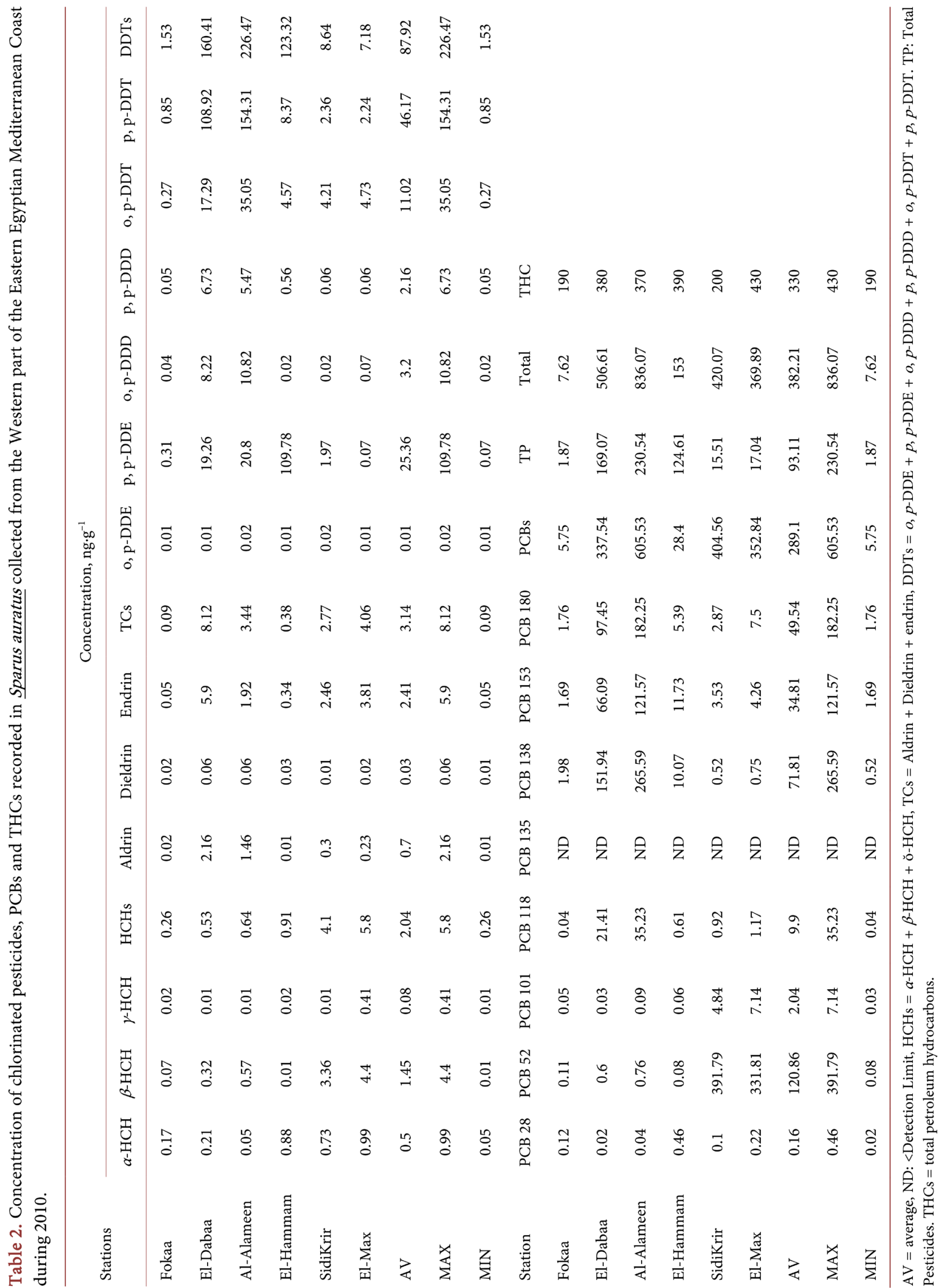


toxic; it is much higher persistent than Dieldrin and its occurrence was expected to be widespread. Relative to HCHs, biota recorded high levels of DDTs showing that, $p, p-D D T$ was the predominant isomer in fish species, with $88.43 \%$ of all DDTs. The mean compositions of o, p-DDE, p, p'-DDE, o, p-DDD, p, p'-DDD, o, p-DDT and p, p'-DDT in biota were $0.84 \%, 3.95 \%, 1.03 \%, 4.05 \%, 2.07 \%$ and $88.43 \%$, respectively. DDD levels were higher than DDE suggesting that DDTs endure the anaerobic transformation in organisms. Metabolic transformation of DDT under anaerobic conditions, p, p'-DDD is formed [30]. The present study showed that the average concentration of DDTs recorded $75.54 \%$ of all OCPs concentrations. Several authors have observed preferential accumulation of DDT degradation products in aquatic organisms [31]. This phenomenon is due to uptake, metabolism and depuration mechanisms for DDT compounds in muscles [32]. The average ratio of HCHs to DDTs concentration in muscles was 23\%, suggesting excretion of HCHs in marine muscles. Accumulation of PCBs was more pronounced in tissues of Sparus auratus with $164.08 \mathrm{ng} \cdot \mathrm{g}^{-1}$; wet weight. The average concentration of OCPs and PCBs in fish species showed a decreasing trend from PCBs $>$ DDTs $>$ HCHs $>$ TCs. PCBs congeners 28, 52,101, 118, $135,138,153$ and 180 were $0.65 \%, 84.74 \%, 0.89 \%, 0.34 \%$, ND\%, 3.09\%, 9.18\% and $1.10 \%$, respectively in fish species (Table 1 ). The results showed that these compounds probably originated via atmospheric deposition as stated by Doong et al. [33]. PCB52, PCB153, PCB138 and PCB180 were the most detected congeners in all investigated fish species. In contrast, PCB135 was not recorded in Sparus auratus. Contribution of low chlorinated congeners was minimal due to the fact that these congeners have an increased mobility from the substrate to water and therefore more available to aquatic organisms [34]. In addition, they are very susceptible to metabolism and are eliminated in marine environment. Thus, the order of decreasing concentrations in the eastern sector was: HCHs: Sahl Altina $>$ El-Bourllous \& Damietta $>$ Rashid $>$ El-Bourllous $>$ Damietta $>$ Abu-Qir. TCs: Damietta > Rashid $>$ El-Bourllous \& Damietta $>$ Sahl Altina $>$ Abu Qir $>$ El-Bourllous. DDTs: Rashid $>$ Sahl-Altina $>$ El-Bourllous $>$ Damietta $>$ El- Bourllous \& Damietta $>$ Abou Qir. PCBs: Sahl-Altina $>$ Damietta $>$ Rashid $>$ El- Bourllous \& Damietta $>$ El Bourlos $>$ Abou Qir. High concentrations of THCs in $590 \mathrm{ng} \cdot \mathrm{g}^{-1}$ were measured in Damietta area. Concentrations of THCs in Sparus auratus varied in a narrow range from $350-590 \mathrm{ng} \cdot \mathrm{g}^{-1}$; with an average of $450 \mathrm{ng} \cdot \mathrm{g}^{-1}$.

On the same context, the mean composition of OCPs in Sparus auratus was 2.19\%, 3.37\%, 94.43\% for HCHs, TCs and DDTs, respectively. DDTs composition was much higher than TCs and $\mathrm{HCHs}$, which might be attributed to the more bio-accumulative ability of DDTs (Table 2). The most striking difference in HCHs composition of the investigated Sparus auratus (approximately $24.51 \%$ of $\alpha-\mathrm{HCH}, 71.08 \%$ of $\beta-\mathrm{HCH}$ and $3.92 \%$ of $\gamma-\mathrm{HCH}$ ) is the high level of $\beta-\mathrm{HCH}$ was the predominant isomer of $\mathrm{HCHs}$ which can exist in the environment for several years as stated by Willett et al. [29]. Although, Aldrin is readily converted to Dieldrin in many environmental compartments, the mean composition of 
Aldrin, Dieldrin and Endrin in Sparus auratus of the present study was $22.29 \%$, $0.96 \%$ and $76.75 \%$, respectively. This indicates that there is a fresh source of Aldrin with no sufficient oxygen available for the oxidation process to its epoxide form; Dieldrin. Endrin is highly toxic; it is much higher persistent than Dieldrin and its occurrence was expected to be widespread in fish species of the western sector. Relative to $\mathrm{HCHs}$, biota recorded high levels of DDTs showing that, $\mathrm{p}$, p-DDT was the predominant isomer in fish species, with $52.51 \%$ of all DDTs. The mean compositions of o, p-DDE, p, p'-DDE, o, p-DDD, p, p'-DDD, o, p-DDT and p, p'DDT in Sparus auratus were 0.01\%, 28.84\%, 3.64\%, 2.46\%, $12.53 \%$ and $54.51 \%$, respectively.

DDE levels were higher than DDD suggesting that DDTs endure the aerobic transformation in organisms. Metabolic transformation of DDT under aerobic conditions, p, p'-DDE is formed [30]. The present study showed that the average concentration of DDTs recorded $94.43 \%$ of all OCPs concentrations. The average ratios of $\mathrm{HCH}$ to DDTs concentration in muscles was $2.32 \%$, suggesting excretion of $\mathrm{HCHs}$ in marine muscles. Accumulation of PCBs was more pro-

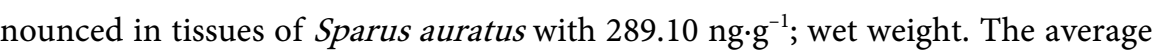
concentration of OCPs and PCBs in fish species showed a decreasing trend from PCBs $>$ DDTs $>$ TCs $>$ HCHs. PCBs congeners 28, 52,101, 118, 135, 138, 153 and 180 were $0.06 \%, 41.81 \%, 0.71 \%, 3.42 \%$, ND\%, $24.84 \%, 12.04 \%$ and $17.14 \%$, respectively in fish species (Table 2). The results showed that these compounds probably originated via atmospheric deposition as stated by Doong et al. [33]. PCB52, PCB153, PCB138 and PCB180 were the most detected congeners in all investigated fish species. In contrast, PCB135 was not recorded in Sparus auratus in the western sector as also happened in the eastern one. The order of decreasing concentrations in all Sparus auratus samples of the Western part was HCHs: El-Max > Sidi Krir > El-Hammam > Al-Alameen > El-Dabaa > Fokaa, TCs: El-Dabaa $>$ El-Max $>$ Al-Alameen $>$ Sidi Krir. $>$ El-Hammam $>$ Fokaa, DDTs: Al-Alameen $>$ El-Dabaa $>$ El-Hammam $>$ Sidi Krir $>$ El-Max $>$ Fokaa and PCBs: Al-Alameen $>$ Sidi Krir $>$ El-Max $>$ El-Dabaa $>$ El-Hammam $>$ Fokaa. Maximum concentrations of THCs were observed at El-Max; $430 \mathrm{ng} \cdot \mathrm{g}^{-1}$, El-Hammam; $390 \mathrm{ng} \cdot \mathrm{g}^{-1}$, El-Dabaa; $380 \mathrm{ng} \cdot \mathrm{g}^{-1}$ and Al-Alameen; $370 \mathrm{ng} \cdot \mathrm{g}^{-1}$. THCs varied from 190 - $430 \mathrm{ng} \cdot \mathrm{g}^{-1}$, with an average of $330 \mathrm{ng} \cdot \mathrm{g}^{-1}$ (Table 2).

The maximum permissible levels of toxic DDTs, PCBs and TCs recommended by the National Academy of Sciences and National Academy of Engineering [35] for the protection of aquatic biota are $1000-5000 \mathrm{ng} / \mathrm{g}$ for PCBs and $100 \mathrm{ng} / \mathrm{g}$ for cyclodienes (all as weight concentration in whole body tissues). The levels recommended by the Swedish Food Regulation are $5000 \mathrm{ng} / \mathrm{g}$ for DDTs, 2000 ng/g for PCBs, and $200 \mathrm{ng} / \mathrm{g}$ for HCHs [36]. The US Food and Drug Administration (FDA) tolerance limit is $2000 \mathrm{ng} / \mathrm{g}$; wet weight for total PCBs in fish and shellfish [28] [37]. All these levels were higher than those recorded in the present study either in Sparus auratus recorded in both of the Eastern and the Western sectors. 


\section{References}

[1] Emara, H.I., Shreadah, M.A., Maoustafa, T.H. and El-Deek, M.S. (1992) Effects of Sewage and Industrial Wastes on the Chemical Characteristics of the Eastern Harbor and El-Max Bay Waters of Alexandria, Egypt. Science of the Total Environment, 112, 773-784.

[2] Said, M.A., El-Deek, M.S., Mamoud, T.H. and Shreadah, M.A. (1994) Effect of Pollution on the Hydrochemical Characteristics of Different Water Types in El-Mex Bay Area West of Alexandria, Egypt. Acta Adriatica, 34, 9-19.

[3] Tayel, F.R. and Shriadah, M.A. (1996) Fe, Cu, Mn, Pb and Cd in Some Fish Species from the Western Harbor of Alexandria, Egypt. Bulletin of the National Institute of Oceanography and Fisheries, 22, 85-96.

[4] Shakweer, L., Shriadah, M.A., Fahmy, M.A. and Abdel Fattah, L.A. (2006) Distributions and Concentrations of Trace Elements along the Mediterranean Coastal Water of Egypt. Egyptian Journal of Aquatic Research, 32, 95-127.

[5] Emara, H.I., Said, T.O., El Naggar, N.A. and Shreadah, M.A. (2008) Aliphatic and Polycyclic Hydrocarbon Compounds as Chemical Markers for Pollution Sources in Relation to Physico-Chemical Characteristics of the Eastern Harbour (Egyptian Mediterranean Sea). Egyptian Journal of Aquatic Research, 34, 1-19.

[6] Fathy, S.A., Abdel Hamid, F.F., Shreadah, M.A., Mohamed, L.A. and El-Gazar, M.G. (2012) Application of Principal Component Analysis for Developing Water Quality Index for Selected Coastal Areas of Alexandria Egypt. Recourses and Environment Journal, 2, 297-305.

[7] Shreadah, M.A., Masoud, M.S., Khattab, A.M. and El Zokm, G. (2014) Impacts of Different Drains on the Seawater Quality of El-Mex Bay (Alexandria, Egypt). Journal of Ecology and the Natural Environment, 8, 287-303.

[8] Abdel-Fatah, L., Fahmy, M.A. and Shriadah, M.A. (2003) Zn, Cu, Cd, Pb and Hg in the Egyptian Coastal Sediments along the Mediterranean Sea. Association for Modeling and Simulation in Enterprise, 64, 55-69.

[9] Shriadah, M.A., Said, T.O., Younis, A.M. and Farag, R.S. (2006) Speciation of Organotin Compounds in Sediments of Semi-Closed Areas along the Mediterranean Coast of Alexandria. Chemistry and Ecology, 22, 395-404. https://doi.org/10.1080/02757540600917443

[10] Abdel Ghani, S.A., Shobier, A.H., Said, T.O. and Shreadah, M.A. (2010) Organotin Compounds in Egyptian Mediterranean Sediments. Egyptian Journal of Aquatic Research, 36, 221-229.

[11] Shreadah, M.A., Said, T.O., Abdel Moniem, M.I., Fathallah, E.M.I. and Mahmoud, M.E. (2011) PAHs in Sediments along the Semi-Closed Areas of Alexandria, Egypt. Journal of Environmental Protection, 2, 700-709. https://doi.org/10.4236/jep.2011.26081

[12] Shobier, A.H., Abdel Ghani, S.A. and Shreadah, M.A. (2011) Distribution of Total Mercury in Sediments of Four Semi-Enclosed Basins along the Mediterranean Coast of Alexandria. Egyptian Journal of Aquatic Research, 37, 1-11.

[13] Shreadah, M.A., Abdel Ghani, S.A., Abdel Samie, A.T., Ahmed, A.M. and Hawash, H.B.I. (2012) Mercury and Methyl Mercury in Sediments of Northern LakesEgypt. Journal of Environmental Protection, 3, 254-261.

[14] Abdel Ghani, S.A., Shobier, A.H. and Shreadah, M.A. (2013) Assessment of Arsenic and Vanadium Pollution in Surface Sediments of the Egyptian Mediterranean Coast. Journal of Environmental Technology and Management, 16, 82-101.

[15] Abdel Salam, S., El Zokm, G., Shobier, A., Othman, T. and Shreadah, M.A. (2013) 
Metal Pollution in Surface Sediments of Abu Qir Bay and the Eastern Harbour of Alexandria, Egypt. Egyptian Journal of Aquatic Research, 39, 1-12.

[16] Shriadah, M.A. (1992) Trace Elements Concentration in Fish Samples from Alexandria Region. The Bulletin of the High Institute of Public Health, 22, 437-444.

[17] Said, T.O., Farag, R.S., Younis, A.M. and Shreadah, M.A. (2006) Organotin Species in Fish and Bivalves Samples Collected from the Egyptian Mediterranean Coast of Alexandria, Egypt. Bulletin of Environmental Contamination and Toxicology, 77, 451-458. https://doi.org/10.1007/s00128-006-1086-8

[18] El Deeb, M.K.Z., Said, T.O., El Naggar, M.H. and Shreadah, M.A. (2007) Distribution and Sources of Aliphatic and Polycyclic Aromatic Hydrocarbons in Surface Sediments, Fish and Bivalves of Abu Qir Bay. Bulletin of Environmental Contamination and Toxicology, 78, 373-379. https://doi.org/10.1007/s00128-007-9173-z

[19] Shreadah, M.A., Fahmy, M.A. and Abdel Fattah, L. (2015) Heavy Metals in Some Fish Species and Bivalves from the Mediterranean Coast of Egypt. Journal of Environmental Protection, 6, 1-9. https://doi.org/10.4236/jep.2015.61001

[20] Fathy, S.A., Abdel Hamid, F.F., Shreadah, M.A., Mohamed, L.A. and El-Gazar, M.G. (2012) Effect of Some Environmental Pollutants on Enzymatic and Total Antioxidant Activities in Tilapia Niloticus. Blue Biotechnology Journal, 1, 433-443.

[21] Said, T.O., Okbah, M.A., Salam, L.A. and Othman, I.M. (2015) Detection of Persistent OCPs and PCBs Congeners in the Near-Shore Coastal Waters of Alexandria, Egypt. Environmental Monitoring and Assessment, 187, 353.

https://doi.org/10.1007/s10661-015-4537-Z

[22] Shreadah, M.A., Said, T.O., Othman, I.M., Fathallah, E.M.I. and Mahmoud, M.E. (2012) Polychlorinated Biphenyls and Chlorinated Pesticides in Sediments along the Semi-Closed Areas of Alexandria, Egypt. Journal of Environmental Protection, 3, 141-149.

[23] Shreadah, M.A., Said, T.O., Othman, I.M., Fathallah, E.M.I. and Mahmoud, M.E. (2014) Organochlorines in Seawater from Egyptian Mediterranean Coast of Alexandria. Development in Analytical Chemistry, 1, 19-24.

[24] Koziol, S.A. and Pudykiewicz, A.J. (2001) Global-Scale Environmental Transport of Persistent Organic Pollutants. Chemosphere, 45, 1181-1200.

[25] Warren, N., Allana, I.J., Carter, J.E., House, W.A. and Parker, A. (2003) Pesticides and Other Micro-Organic Contaminants in Freshwater Sedimentary Environments: A Review. Applied Geochemistry, 18, 159-194.

[26] UNEP/IOC/IAEA (1991) Sampling of Selected Marine Organisms and Sample Preparation for the Analysis of Chlorinated Hydrocarbons. Reference Methods for Marine Pollution Studies No. 12, Revision 2, United Nations Environment Program 17, Nairobi.

[27] IOC (1993) Chlorinated Biphenyls in Open Ocean Waters: Sampling, Extraction, Clean-Up and Instrumental Determination. Manual and Guides No. 27, Intergovernmental Oceanographic Commission, UNESCO36, Pairs.

[28] Kannan, K., Tanabe, S., Giesy, P.J. and Tatsukawa, R. (1997) Organochlorine Pesticides and Polychlorinated Biphenyls in Foodstuffs from Asian and Oceanic Countries. Reviews of Environmental Contamination and Toxicology, 152, 1-55. https://doi.org/10.1007/978-1-4612-1964-4_1

[29] Willett, L.K., Ulrich, M.E. and Hites, A. (1998) Differential Toxicity and Environmental Fates of Hexachlorocyclo-Hexane Isomers. Environmental Science and Technology, 32, 2197-2207. https://doi.org/10.1021/es9708530

[30] Albone, S.E., Eglinton, G., Evans, C.N., Hunter, M.J. and Rhead, M.M. (1972) Fate 
of DDT in Severn Estuary Sediments. Environmental Science and Technology, 6, 914-919. https://doi.org/10.1021/es60069a009

[31] Qiang, Z.F. (2004) Organochlorines in Sediments and Mussels Collected from Coastal Sites along the Pearl River Delta, South China. Journal of Environmental Sciences, 16, 321-327.

[32] Sapozhnikova, Y., Bawardi, O. and Schlenk, D. (2004) Pesticides and PCBs in Sediments and Fish from the Salton Sea, California, USA. Chemosphere, 55, 797-809.

[33] Doong, A.R., Sun, C.Y., Liao, L.P., Peng, K.C. and Wu, C.S. (2002) Distribution and Fate of Organochlorine Pesticides Residues in Sediments from the Selected Rivers in Taiwan. Chemosphere, 48, 237-246.

[34] De Boer, J., Van der Zande, E.T., Pieters, H., Ariese, F., Schipper, A.C. and Van Brummelen, T. (2001) Organic Contaminants and Trace Metals in Flounder Liver and Sediment from the Amsterdam and Rotterdam Harbors and off the Dutch Coast. Journal of Environmental Monitoring, 3, 386-93. https://doi.org/10.1039/b103814c

[35] National Academy of Sciences and National Academy of Engineering (1972) Ecology Research Serves Environmental. NAS-NAE, Washington DC, 1-62.

[36] SFR, Foreign Substances in Food, and the National Food Administration SLVFS (1983) Swedish Food Regulation, Uppsala. 1.

[37] Henry, S.K., Kannan, K., Nagy, W.B., Kevern, R.N., Zabik, J.M. and Giesy, P.J. (1998) Concentrations and Hazard Assessment of Organochlorine Contaminants and Mercury in Smallmouth Bass from a Remote Lake in the Upper Peninsula of Michigan. Archives of Environmental Contamination and Toxicology, 34, 81-86. https://doi.org/10.1007/s002449900288

\section{Submit or recommend next manuscript to SCIRP and we will provide best service for you:}

Accepting pre-submission inquiries through Email, Facebook, LinkedIn, Twitter, etc. A wide selection of journals (inclusive of 9 subjects, more than 200 journals)

Providing 24-hour high-quality service

User-friendly online submission system

Fair and swift peer-review system

Efficient typesetting and proofreading procedure

Display of the result of downloads and visits, as well as the number of cited articles

Maximum dissemination of your research work

Submit your manuscript at: http://papersubmission.scirp.org/

Or contact ojms@scirp.org 